\title{
Technosphere-Urban Society and its Problems
}

\author{
Mikhail Mamichev*, and Elena Dergacheva \\ Bryansk State Technical University, 241035 Bryansk, Russia
}

\begin{abstract}
The technosphere which is the artificial shell of the Earth can be considered the contemporary result of developing the society and the world as a whole. The technosphere, being a complex system, contains entire regions, urban agglomerations, industrial zones, industrial and domestic environments. New technospheric conditions include people's living conditions in cities and industrial centres, production, transport and life amenities. As a consequence, the society from the primary biological becomes technospheric one, i.e. the society dominated by artificial components. When studying the technosphere-urban society, the author uses the methodology of the socio-natural approach, based on the works of V.I. Vernadsky about changing the biosphere by the scientifically organized human mind and forming the noosphere. The basis of this scientific approach to the world study is researching the society and nature, the Earth reality on the basis of their interconnected social and natural development. Technogenic changes taking place in the world (the growing role of the urbanized environment, genetic engineering, living organism cloning) are inevitable. The technosphere-urban society will be the society of the future, created by the technosphere and the global technological development.
\end{abstract}

\section{Introduction}

Considering the problem of the society development, taking into account the city influence, one should understand what a modern city is. The city development began at the dawn of human existence, namely about 10-12 thousand years ago. The first permanent settlements, such as Damascus (originated about 12 thousand years ago) or Jericho (about 9 thousand years ago), were not yet the cities in our understanding. It is believed that the time of their emergence roughly coincided with the Neolithic Agrarian Revolution, that is, people's transition from hunting and gathering to agriculture. At the same time, hunters led a healthier lifestyle, as they ate well and variedly (regularly ate meat and fruit, for example), moved a lot, rarely met people and, as a result, were less likely to get sick. And the newly appeared farmers suffered from a meagre diet, epidemics and the necessity to constantly work.

Undoubtedly, cities made it possible to concentrate human and material resources, obtained a significant advantage in the productive force growth. A large-scale division of labor appeared in the cities as due to provision stocks the townspeople stopped cultivating

\footnotetext{
* Corresponding author: mamichevm@bk.ru
} 
the land and turned to other occupations namely complex crafts, trade, knowledge development, and worship. Many ancient cities grew rich and acquired important political and cultural significance. This is how the fundamental principle of urban development based on scale economies was formed: a city concentrated resources and the most efficient productive forces within its borders, displaced less profitable occupations to the periphery, and became a growth point for vast surrounding spaces.

Mentioning the cities of the ancient world, one cannot fail to say about the greatest city such as Rome. It is Rome that can be called a vivid example of the city growing role in the society life. Buildings and structures, artificially created sewer canals, thermal baths and other aspects of a comfortable social life attracted people from all over the world.

The urban society was different from the society of rural settlements. Living in cities, a person was gifted with the benefits of civilization, in connection with which the life expectancy increased, the level of medicine and nutrition improved. The society became developed and literate, in contrast to the rural settlements where it was different and distant for the residents. Our research will make it possible to understand why humanity began to concentrate in the urbanized environment, what served this fact and what will be the society formed in a comfortable urban environment.

To date, the scale of the technosphere in its power and mass is similar to the biosphere remnants, which is gradually losing its functions for the life reproduction. Moreover, the technosphere is concentrated in the urbanized environment, in which more than half inhabitants of the Earth (that is 4.6. billion people) lived in 2019.

Under the influence of the mankind's scientific and technogenic activities, a global technogenic socio-natural system of life in a technosphere-urban environment is formed, in which a technogenic society, technogenically modified nature (biotechnological plants and living organisms) and the remains of natural nature coexist. An important component of the aforementioned system is a technogenically altered person (with weakened natural health and various inclusions of artificial components in the body from drugs to biotechnological organs to support life. This is already a new technogenic and even postbiospheric world, which researchers write about $[4,5,6,7,8]$.

Technospherizing the planet Earth, creating an urbanized environment, weakening the biosphere and natural biological processes significantly affect the human society living in these conditions. At the same time, the city development gives humanity a number of vital advantages in the form of advanced medicine, social policy, technical aspects that simplify the human society life. Simultaneously, growing cities create the danger of losing not only the biosphere as a self-developing system, but also universal humane principles in the society, creating an artificial, technospheric, indifferent society, the purpose of which is only its own comfort and enrichment.

\section{Materials and Methods}

The society living in the conditions of the world technogenic development is a complex and multifaceted component that influences the surrounding world.

The technogenic aspects of developing the modern world, consisting in the predominance of the artificial environment, nurture the society whose existence is permeated with technological components. The modern technospheric society, absorbing the artificial environment benefits, forgets about the essence of man as a humane creator and former of the world, the priority is not given to humanity in relation to the biosphere, flora and fauna, natural resources, and even to the fellows, but to getting the maximum life comfort obtained using artificial components.

It cannot be denied that maintaining a favorable life environment for the society in the biosphere depends on the human activity rationality. The human society cannot be 
considered only as a system based solely on the social laws of development without connection with the natural-biological ones, as it is indicated by researchers of sociotechnological natural processes. Therefore, in the study of the substantive aspects of such a society, along with the theories of V.G. Fedotova, D. Harvey, D. Rawls, and others, generally recognized in social philosophy, [3], the methodology of the socio-natural approach is used based on the works of V.I. Vernadsky about the biosphere and noosphere (i.e., the intelligent shell of the planet) of the first half of the twentieth century and developed in the works of modern researchers of socio-technological processes, E.S. Demidenko, E.A. Dergacheva, K.V. Dergachev, N.V. Popkova , I. Wallerstein, A. Chumakov and others $[10,11,12,13,14]$. In their works, social changes in the life system are considered in direct relationship with natural, and now also technogenic ones, the interaction of which is mediated by the socially formed technosphere.

It is undeniable that the role of cities, with social systems that have developed within them, is very great, and the problems of modern civilization can be called typical urban problems. The very fact that the population of today's technogenic world is largely urban, and that the urbanization process and the way of life that is consistent with it has radically transformed the whole world in a short time, proposes that almost any meaningful statement that can be made about today's society, will contain urbanism as one of its causal terms. Moreover, almost any statement intended to explain the problems affecting the cultural values of the modern technospheric society will necessarily have to include the modern urban social structure, either as an independent or as a dependent variable. Conversely, an attempt to understand the city inevitably leads us to the main aspects of the human civilization development.

\section{Results and discussions}

Modern cities have an unimaginable technical diversity. A striking example of a modern technically developed city is Tokyo, the capital of Japan. All innovations of the human development are concentrated in this city. Robotic transportation and manufacturing, replacing the human labor with that of artificial intelligence and robots, all of this is located inside Tokyo. Moreover, Japanese scientists are seriously determined to create an "ideal" city, where the human society will stop thinking about the challenges of existence and live in the comfort created by technology. Such a project is called the "Woven City" or Fujisawa. All objects of the "Woven City" will receive electricity from the station operating on hydrogen fuel cells, and the water obtained in the form of "exhaust" will also be used to ensure the settlement life. Solar panels will be placed on the roofs of all buildings. The houses will have sensors that control the parameters of the residents' bodies, and in case of any deviations, people will be warned about the need to visit a doctor. To service the streets and infrastructure, the "Woven City" will use artificial intelligence robots.

The reality is that such cities will start to appear all over the world and create a completely new artificial technosphere-urban society, which can be called an artificial society. In the technosphere-urban society, with a predominance of technical aspects, the meaning of its people's traditions, its cultural values is lost for a person, their place is taken by the values of the virtual reality, the cult of computer technology, which in turn often adversely affects a person's attitude towards his or her own kind. A dangerous component of transforming a biological society into a technosphere-urban society is the priority of consumerism. In the consumer society there is a substitution of values, criteria that are truly human in a person, for artificial ones. A person in the consumer society feels valuable, selfsufficient, worthy of self-esteem if he or she has a well-defined consumer behavior, and not personal qualities. The structure of a human consumer's intrinsic value includes the criteria for having various "toys" such as a prestigious car, an expensive cell phone, various 
services and goods that are dictated by fashion, and not by an urgent need. And such a person begins to value themselves not for their own personal achievements, but for the fact that he or she has various fashionable toys or redundant things.

While developing, the technosphere-urban society simplifies its existence and creates a comfortable urban technosphere-developed urban environment. The product of such comfort is the world digitalization. Speaking about digitalization, it should be noted that this is an indicator of effective world development, covering production, business, science, social sphere and ordinary human life. The society digitalization makes it possible not only for specialists, but also for ordinary citizens to form a technologically comfortable environment that combines digital information about the world around us, a technological and instrumental basis that simplifies the life of a technospheric person and the technosphere-urban society as a whole.

Under the consumer society dominance, the principle of the society humanity and social justice is lost. A negative scenario, when the consumption becomes the society sole main goal, when cities absorb the last natural territories, will lead the humanity to regression and inevitable death in the form we know it today. In the consumer society, an individual gets pleasure not so much from the object itself as from the possibility of realizing their creative potential. Such a society is based the creator's hedonism not on a passive consumer's hedonism" [2]. An interesting opinion about the consumer society was expressed by Z. Bauman: "the way in which today's society "forms" its members dictates, first of all, the obligation to play the consumers' role" [1]. The technosphere-urban consumer society can be defined as using information products and technologies for the widest and fastest possible satisfaction of any existing needs. This synthetic society was formed, firstly, under the influence of the abundance of goods and services supply in the cities of a constantly updated array of various goods and services and, secondly, under a huge potential of total informatization, used for the unlimited distribution of not only these goods and services, but for creating appropriate targets, interests and consumer preferences. The scarcity of natural resources and the displacement of agriculture by urban agglomerations will create sharp disagreements between the world leaders, as well as the death of outsider countries. The technosphere-urban society has already become an integral part of the modern world. And only the presence of the rationality principles in the technosphere influence on our planet development, on which the future model of human life will be built, with an obligatory condition for the biospheric life preservation, will allow not only preserving the ecological environment that already exists, but also increasing it.

\section{Conclusion}

In conclusion, we note that the city is not just a point where a large mass of people is accumulated in a limited space; it is also gathering people, exhibiting the most extraordinary heterogeneity in almost all the characteristics in which people may differ from one another. The technosphere-urban society is a society of the future, where artificial technical aspects are the basis of life, where the world digitalization becomes the primary basis of life. At the same time, we believe that, as in all other societies, people differ here by gender and age, vary in occupation, due to a wider division of labor that has become possible thanks to developing cities and the technosphere. People in such a society also differ in wealth and income, occupying different positions in a range, at one end of which we find the extremes of abundance, and at the other we see the depths of dire poverty and insecurity. The human society of the future should understand that despite the inevitability of the technology development and the life simplification, one should not forget about the humanity and justice both to the world around and to the person as a whole. 


\section{References}

1. Z. Bauman, Globalization, The Human Consequences (2004)

2. V.I. Ilyin, Journal of Sociology and Social Anthropology, 5(58), 41 (2011)

3. D. Harvey, Social Justice and the City (2018)

4. E.A. Dergacheva, Philosophy of the Technogenic Society (2011)

5. Social Justice in Russian, http://lawinrussia.ru/

6. K.V. Dergachev, The European Proceedings of Social \& Behavioural Sciences, International Conference «Responsible Research and Innovation 2016», 209 (2016)

7. E.A. Dergacheva, O.E. Backsanskij, International Conference «Responsible Research and Innovation 2016», 192 (2016)

8. I. Wallerstein, The End of the Familiar World: Sociology of the XXI century (2004)

9. A. Chumakov, The Globalized World from the Philosophical Point of View, Chinese Edition (2018)

10. E.S. Demidenko, E.A. Dergacheva, N.V. Popkova, The Philosophy of the World Social and Technogenic Development: articles, concepts, terms, The world informencyclopedia (2011)

11. E.S. Demidenko, SHS Web of Conferences, RPTSS 2015 - International Conference on Research Paradigms Transformation in Social Sciences 2015, 28 (2016)

12. N.V. Popkova, Philosophy of the Technosphere (2008)

13. Economy in the Conditions of Social and Technogenic Development of the World, 1st and 2nd International interdisciplinary scientific conference on fundamental and applied problems of modern socio-economic and economic-ecological development, $(1,2),(2016,2017)$ 